\title{
Using thermal time models to predict the impact of assisted migration on the synchronization of germination and shoot emergence of oak (Quercus robur L.)
}

\author{
Shelagh A. McCartan • Richard L. Jinks • Nadia Barsoum
}

Received: 6 November 2014 / Accepted: 26 December 2014 / Published online: 28 January 2015

(C) INRA and Springer-Verlag France 2015

\begin{abstract}
- Key message Climate change will affect regeneration. Assisted migration is a climate change adaptation strategy that is associated with risks regarding transfer distance. Thermal time models can provide information about the synchronization of regeneration with seasons and the implications for assisted migration.

- Context Climate change may prevent trees from adapting or migrating fast enough to track their climatic envelopes. Assisted migration facilitates gene flow by sourcing preadapted provenances usually from southerly regions representative of future climates.

- Aim The aims were to develop thermal time models for the germination and shoot emergence of two provenances of Quercus robur and to predict the impact of assisted migration on the synchronization of regeneration with seasons.
\end{abstract}

\section{Handling Editor: Erwin DREYER}

Contribution of the co-authors SAM designed the experiment, analysed the data and wrote the paper. RLJ developed the thermal time models, analysed the data, plotted Figs. 2, 3 and 4, and contributed to the paper. NB formulated the project concept, secured project funding, sourced seeds and contributed to the paper.

S. A. McCartan · R. L. Jinks

Centre for Sustainable Forestry and Climate Change, Forest

Research, Surrey, England, UK

R. L. Jinks

e-mail: richard.jinks@forestry.gsi.gov.uk

N. Barsoum

Centre for Ecosystems, Society and Biosecurity, Forest Research,

Surrey, England, UK

e-mail: nadia.barsoum@forestry.gsi.gov.uk

S. A. McCartan $(\square)$

Forest Research, Alice Holt Lodge, Farnham, Surrey GU10

4LH, England, UK

e-mail: shelagh.mccartan@forestry.gsi.gov.uk
- Methods Using cumulative germination (radicle emergence) and shoot emergence data from a laboratory experiment, thermal time models were developed for the seedling emergence of $Q$. robur. Thermal time parameters were then used with climatic data to predict the timing of germination and shoot emergence for English and Italian provenances in southern England.

- Results The thermal time parameters were lower for germination than shoot emergence, resulting in their temporal separation. For Italian acorns, base temperature was lower, but thermal time required was higher for germination and shoot emergence compared to English acorns indicating local adaptation. Predictions suggest little difference in the timing of germination and shoot emergence for the two provenances in the future climate of southern England (2080s).

- Conclusions Q. robur has a robust regeneration mechanism where the thermal time parameters constrain germination and shoot emergence to safe windows and thereby ensure synchronization with seasons.

Keywords Climate change - Epicotyl dormancy · Provenance $\cdot$ Regeneration $\cdot$ Thermal time models

\section{Introduction}

In Britain, the mean annual temperature is projected to rise between 3 and $6{ }^{\circ} \mathrm{C}$ by the 2080s with larger increases in winter than summer (Broadmeadow and Ray 2005; Broadmeadow et al. 2005). In a rapidly changing climate, therefore, species may not be able to migrate or adapt fast enough to cope with the projected emission scenarios (Aitken et al. 2008; Broadmeadow et al. 2005). This may result in adaptational lag due to a lack of gene flow, 
particularly at the trailing edge of populations (Aitken et al. 2008; Hewitt and Nichols 2005). Yet, it is critical that genetic diversity is retained within populations, thereby safeguarding the adaptive potential of Britain's forests to future climates (Hubert and Cottrell 2014). Assisted migration is often proposed as a management tool to enable species to track climatic envelopes in a changing climate (Leech et al. 2011). This involves sourcing seeds from provenances usually from more southerly latitudes $\left(2-5^{\circ}\right)$ that may be pre-adapted to the future climate (Ray et al. 2010). However, assisted migration is also associated with different levels of risk including maladaptation depending on the transfer distance (Leech et al. 2011; Ste-Marie et al. 2011). In the northern hemisphere, Quercus robur is an important component of temperate forests. It has a wide geographical distribution, occurring naturally across most of temperate Europe into parts of North Africa and as far east as the Balkans, Urals and Caucasus (Suszka et al. 1996; Jones 1959). Q. robur is genetically diverse, which is probably due to the large population sizes, long-distance geneflow and inter-fertility (Ducousso and Bordacs 2004). At present, however, the EU Directives and the OECD scheme for Forest Reproductive Material advise that reproductive material must be transferred at a local scale and that transfers among provenance regions must be strictly limited (Ducousso and Bordacs 2004). Nevertheless, seeds that are sown now may as mature trees experience a climate similar to that of a latitude two or three degrees further south (Broadmeadow et al. 2005; Hubert and Cottrell 2007). This is critical as temperature is the main environmental cue regulating regeneration. In this study, the impact of assisted migration on regeneration and synchronisation with the seasons is assessed using thermal time models. Thermal time models have previously been developed for Q. robur (Pritchard and Manger 1990) but also for other recalcitrant species including Aesculus hippocastanum (Pritchard et al. 1996, 1999) and Castanea sativa (Pritchard and Manger 1990). These have focussed on germination i.e. radicle emergence and have not included shoot emergence. The overall aims of this study were to (i) develop thermal time models for germination and shoot emergence (ii) and use these models and climatic data to predict the potential impact of assisted migration on future regeneration of $Q$. robur in southern England.

\section{Materials and methods}

\subsection{Provenance selection}

The term provenance refers to the geographic locality of a stand of trees from where the seed was collected (Hubert and Cundall 2006). Two provenances for study were selected by 'climate-matching' the New Forest, southern England $\left(50^{\circ}\right.$ $52^{\prime} \mathrm{N} ; 1^{\circ} 34^{\prime} \mathrm{W}$ ) to regions of Europe that currently experience climatic conditions expected in the future in southern England. This was achieved by inputting the UKCIP04 climate change high carbon emissions scenario data for the 2080s into a climate-matching model that is based on the Ecological Site Classification methodology (Broadmeadow et al. 2005; Pyatt et al. 2001). Mean monthly temperatures, total monthly rainfall amounts and diurnal temperature ranges were compared between regions on an $8-\mathrm{km}$ grid scale. A regional match for the New Forest region that currently experiences climatic conditions predicted in the 2080s is situated in north-eastern Italy within the Commune of Moriago della Battaglia $\left(45^{\circ} 52^{\prime} \mathrm{N} ; 12^{\circ} 6^{\prime} \mathrm{E}\right)$.

\subsection{Seed source}

In autumn 2010, approximately 2000 acorns of $Q$. robur were collected from an oak-dominated woodland in the New Forest, southern England and another within the Commune of Moriago della Battaglia, north-eastern Italy. The acorns were collected from at least 50 trees in each provenance. The acorns were cleaned, spread in thin layers and maintained in cool $\left(2-5^{\circ} \mathrm{C}\right)$ conditions during storage (3-4 weeks). The two seed lots were then sorted to remove insect-damaged and prematurely sprouting acorns prior to the experiment.

\subsection{Temperature response curves}

One hundred acorns were sown horizontally per tray containing moistened peat: grit mixture $(1: 1 v / v)$; acorns were not covered with potting mixture to facilitate assessments. The trays were placed in loosely tied polythene bags, and then cohorts were incubated over a range of constant temperatures $\left(5,10,15,20,25,30\right.$, and $\left.35^{\circ} \mathrm{C}\right)$. There were two trays per provenance at each temperature, which were re-randomized in the incubators at each assessment. At weekly intervals, the acorns were assessed for germination and shoot emergence. Acorns were considered germinated when the radicle lengths were $2 \mathrm{~mm}$ or longer. Shoot emergence was recorded when the shoot lengths were $5 \mathrm{~mm}$ or longer. The tests were terminated when there was no further increase in germination and/ or shoot emergence over three consecutive assessments or when there were no apparent viable seeds remaining. The ungerminated acorns were then cut and assessed as fresh, dead or insect-damaged.

\subsection{Thermal time models}

The statistical analyses were carried out using Genstat 13.1 (Payne et al. 1993). Thermal time $(\theta)$ is the number of degrees above base temperature $\left(T_{b}\right)$ that the seeds accumulate over time $(t)$ while at a particular temperature $(T)$, and therefore, thermal time is described by the equation $\theta=\left(T-T_{b}\right) t$ (Bewley et al. 2013; Côme and Corbineau 2006). However, the thermal 
time requirement of seeds can also be represented by the equation probit $(g)=k+\left[\left(T-T_{b}\right) t_{g}\right] / \sigma$ where probit $(g)$ is the germination or shoot emergence in probit units, $k$ is a constant, $\left(T-T_{b}\right) t_{g}$ is the accumulated thermal time for a particular percentile germination or shoot emergence $(g)$, and $\sigma$ is the standard deviation of germination or shoot emergence (Ellis et al. 1986). This equation was generalized and re-parameterized as $\operatorname{logit}(g)=\beta_{1}+\beta_{2}(T t)-\beta_{3} t$ where $\beta_{1}=k ; \beta_{2}=1 / \sigma ;$ and $\beta_{3}=\beta_{2} T_{b}$, so that base temperature $\left(T_{b}\right)$ could be estimated directly as $T_{b}=\left(\beta_{3} / \beta_{2}\right)$ (Jinks et al. 2006). The model was fitted to the laboratory germination and shoot emergence count data obtained at optimal and sub-optimal temperatures $\left(\leq 20^{\circ} \mathrm{C}\right)$ using the GLM procedures of Genstat (Payne et al. 1993), and the significance of provenance differences was tested by analysis of deviance. The maximum number of germinated seeds and emerged shoots recorded in each treatment combination were used as the binomial totals for fitting the models. The base temperature and other thermal time parameters for each provenance were estimated from the fitted parameters (Jinks et al. 2006).

\subsection{Predictions using climatic data}

Figure $1 \mathrm{a}, \mathrm{b}$ shows the climatic data obtained for the two climate-matched regions (1980-2009) using high resolution data from the Climate Research Unit (CRU), University of East Anglia, England (Harris et al. 2012). The latitude and longitude of the CRU grid square selected for the New Forest, England, were $51^{\circ} 25^{\prime} \mathrm{N}$ and $1^{\circ} 45^{\prime} \mathrm{W}$ respectively, while for Moriago della Battaglia, Italy, these were $45^{\circ} 25^{\prime} \mathrm{N}$ and $11^{\circ} 75^{\prime} \mathrm{E}$ respectively. Using the thermal time parameters of the two provenances and mean monthly temperature data for each region, germination and shoot emergence were predicted under reciprocal field conditions.

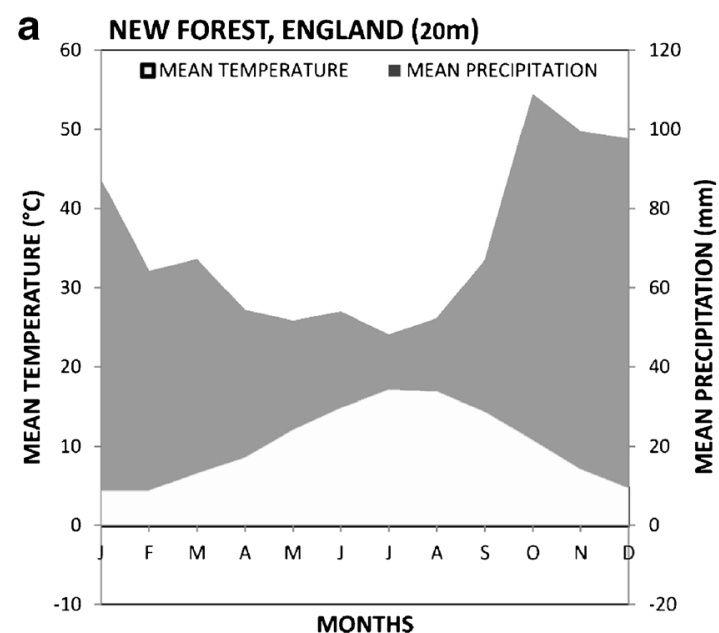

\section{Results}

\subsection{Germination and shoot emergence}

Figures $2 \mathrm{a}-\mathrm{d}$ show the cumulative percentage germination and shoot emergence for the two provenances of acorns incubated at a range of constant temperatures. The parameters for the fitted logistic curves (not shown) for both germination and shoot emergence were similar at sub-optimal and optimal temperatures for English and Italian acorns. However, the rate and maximal germination and shoot emergence differed at supraoptimal temperatures $\left(\geq 25^{\circ} \mathrm{C}\right)$. The values of maximal germination were high due to the very careful pre-selection of the acorns. Generally, at 15 and $20{ }^{\circ} \mathrm{C}$, the acorns germinated promptly and uniformly, reaching maximal germination ranging from 92 to $98 \%$ (Figs. 2a, b). Most acorns germinated within 6-8 weeks and then rapidly produced long tap roots. After a short lag of 4-5 weeks, the epicotyls emerged and then elongated, resulting in normal seedlings with well-developed roots and single shoots. At sub-optimal temperatures (5 and $10{ }^{\circ} \mathrm{C}$ ), the acorns germinated slowly, eventually reaching comparable maximal germination to those recorded at 15 and $20{ }^{\circ} \mathrm{C}$ (Figs. 2a, b). At $10{ }^{\circ} \mathrm{C}$, a similar proportion of acorns produced normal seedlings as at 15 and $20{ }^{\circ} \mathrm{C}$ (Figs. 2c, d), although there was a longer lag (ca. 10 weeks) between germination and shoot emergence. Germination and subsequent radicle growth were slower still at $5{ }^{\circ} \mathrm{C}$, occurring over $15-17$ weeks. While no epicotyls emerged at $5{ }^{\circ} \mathrm{C}$ during the 23-week period, there were signs that shoot emergence was likely viz. elongated cotyledonary petioles and, in some cases, plumules were apparent. At supra-optimal temperatures $\left(\geq 25^{\circ} \mathrm{C}\right)$, the acorns germinated over the same time period but less uniformly than at 15 and $20^{\circ} \mathrm{C}$ (Figs. 2a, b). Often, the acorns produced abnormal seedlings. At $25^{\circ} \mathrm{C}$, the abnormal seedlings had well-developed roots but stunted multistemmed shoots. These abnormal seedlings were included in

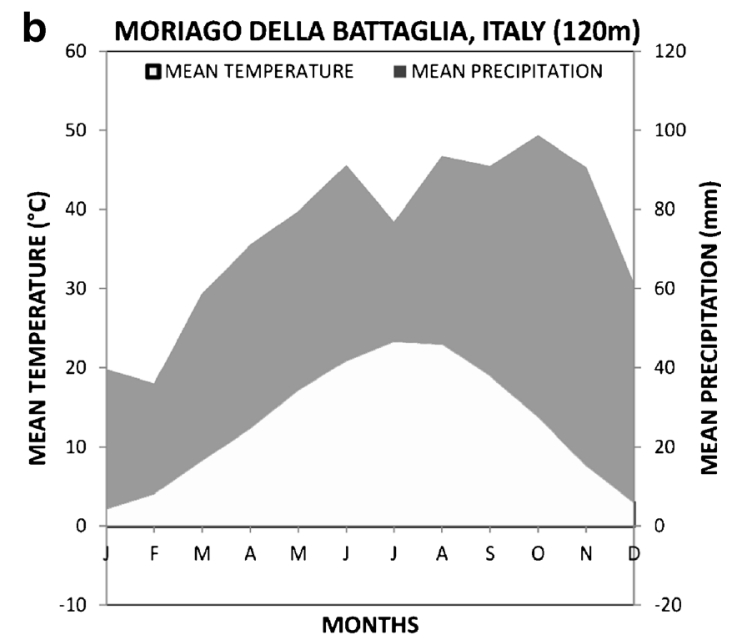

Fig. 1 The climatic data for a England and b Italy averaged over a 30-year period (1980-2009) (CRU) 
Fig. 2 Cumulative percentage germination (a English and b Italian) and shoot emergence (c English and d Italian) for two provenances of acorns incubated over a range of temperatures

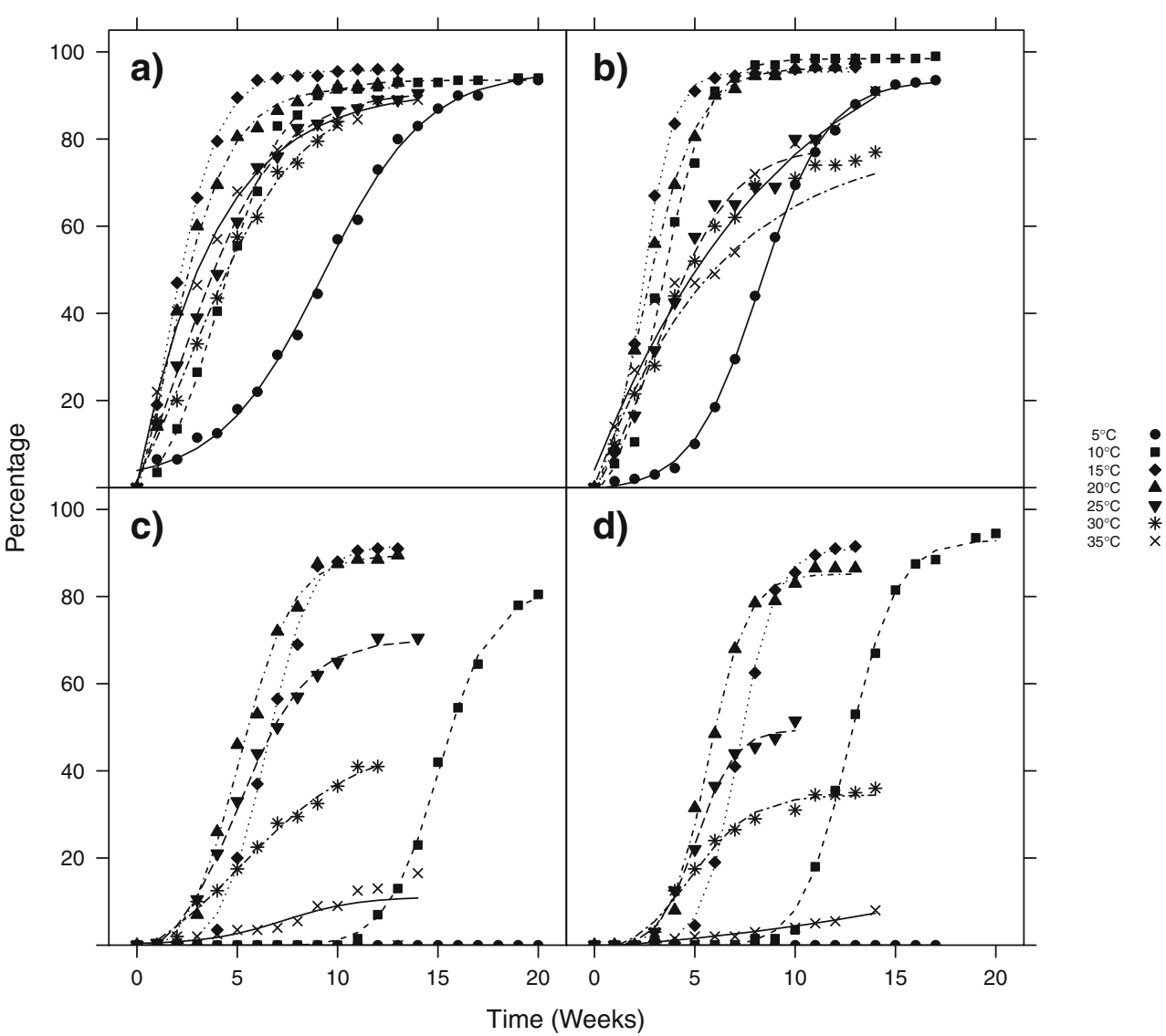

the shoot emergence data as the multi-stemmed shoots only became apparent during the latter assessments. At temperatures $\geq 30^{\circ} \mathrm{C}$, the acorns often chitted and then failed to develop further, or produced abnormally stunted or deformed roots and elongated cotyledonary petioles. These abnormal seedlings were excluded from the shoot emergence data as the roots failed to develop normally. In both cases, the percentage of abnormal seedlings was not recorded. At $30^{\circ} \mathrm{C}$, the cumulative shoot emergence was only 42 and $35 \%$ for English and Italian acorns respectively, decreasing further to 17 and $8 \%$ respectively at $35^{\circ} \mathrm{C}$ (Figs. 2c, d).

\subsection{Thermal time models for germination and shoot emergence}

Thermal time models were derived for germination and shoot emergence using a range of sub-optimal and optimal temperatures $\left(\leq 20^{\circ} \mathrm{C}\right)$ for each provenance. This temperature range was selected as these models assume that there are linear relationships between rate and temperature (Finch-Savage and Whalley 2006). Data for acorns incubated at supra-optimal temperatures $\left(\geq 25^{\circ} \mathrm{C}\right)$ were excluded from the analyses for both germination and shoot emergence as most acorns failed to develop normally. Similarly, the shoot emergence data for acorns incubated at $5{ }^{\circ} \mathrm{C}$ were excluded from the analyses because no epicotyls emerged during the 23-week period. Preliminary analyses showed that there were no significant differences between the two pseudoreplicates (trays) of the provenances at each temperature for either germination (F pr. 0.061) or shoot emergence (F pr. 0.361), and therefore the data were aggregated. Overall, fitting the logit models to counts of germination and shoot emergence accounted for $91.8 \%$ and $94.5 \%$ of the total deviance respectively (Tables 1 and 3). The addition of provenance as a factor in the model for germination showed no significant difference in either the constant or the thermal time coefficient $\left(\beta_{2}\right)$ and a marginally significant difference in the time parameter $\left(\beta_{3}\right)$ (Table 1). Figure $3 \mathrm{a}$ shows the observed and fitted thermal values for

Table 1 Accumulated analysis of deviance for germination count data

\begin{tabular}{llllll}
\hline Change & d.f. & Deviance & $\begin{array}{l}\text { Mean } \\
\text { deviance }\end{array}$ & $\begin{array}{l}\text { Deviance } \\
\text { ratio }\end{array}$ & $\begin{array}{l}\text { Approx. } \\
\text { F. pr. }\end{array}$ \\
\hline +Thermal time $(\theta)$ & & $16,024.39$ & $16,024.39$ & 1373.53 & $<0.001$ \\
+Time & 1 & 300.07 & 300.07 & 25.72 & $<0.001$ \\
+Provenance & 1 & 11.23 & 11.23 & 0.96 & 0.328 \\
$\begin{array}{l}\text { +Thermal time. } \\
\text { provenance }\end{array}$ & 1 & 31.8 & 31.8 & 2.73 & 0.101 \\
$\begin{array}{l}\text { +Time. provenance } \\
\text { Residual }\end{array}$ & 1 & 48.94 & 48.94 & 4.19 & 0.043 \\
Total & 125 & 1458.33 & 11.67 & & \\
& 130 & $17,874.76$ & 137.5 & & \\
\hline
\end{tabular}


Fig. 3 Fitted thermal values for a germination and $\mathbf{b}$ shoot emergence in English (circles) and Italian (squares) acorns. The measured data are represented by the open symbols and the fitted models by the closed symbols

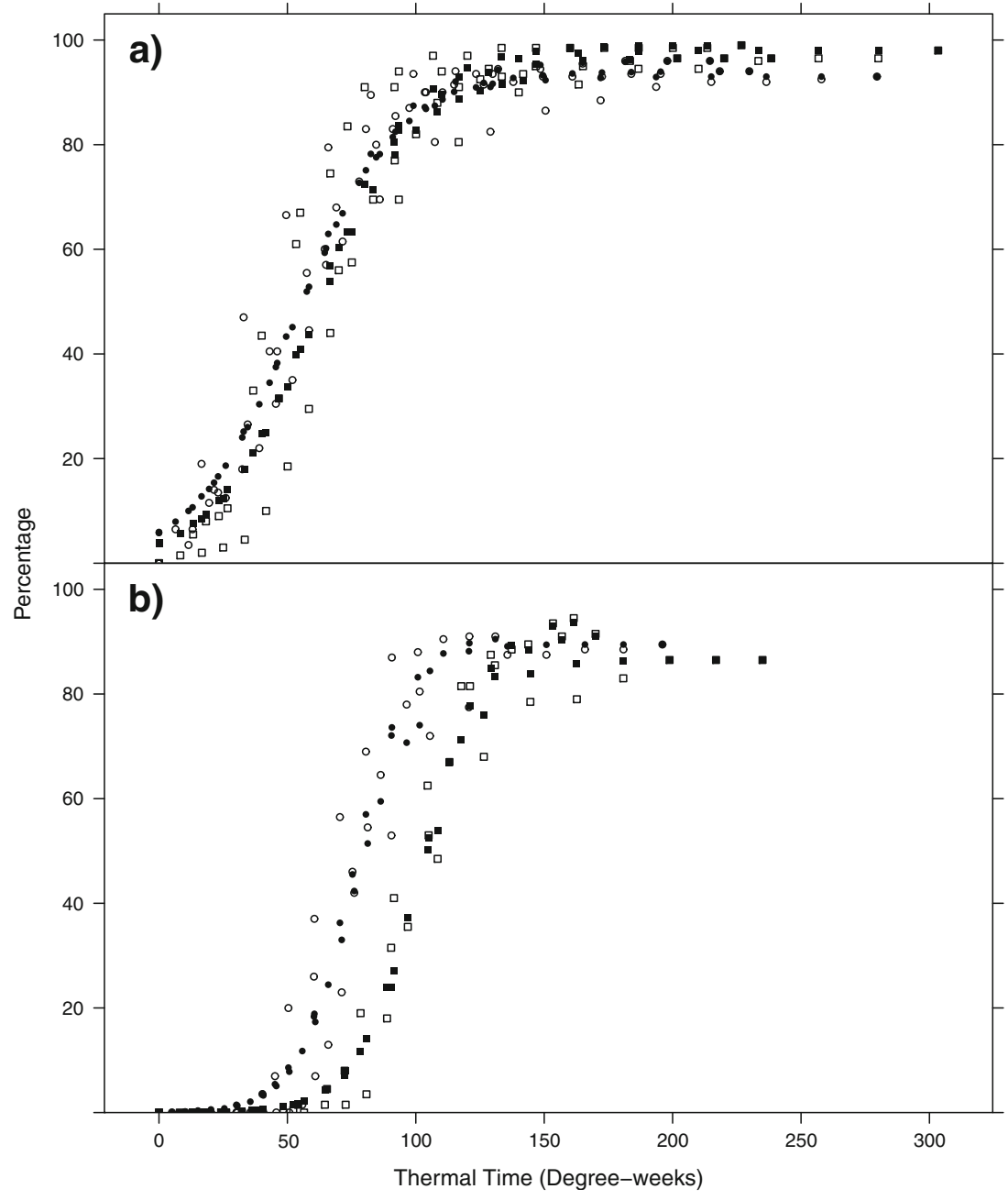

germination, which were similar for both English and Italian acorns. For both provenances, the base temperatures for germination were negative with Italian acorns about $2{ }^{\circ} \mathrm{C}$ lower than the English ones (Table 2). The total thermal time required for $50 \%$ germination was estimated as 53 and 61 weeks for the English and Italian provenances, respectively (Table 2). In contrast to germination, the addition of provenance as a factor to the model for shoot emergence showed significant differences in model parameters between the English and Italian acorns

Table 2 Estimates of the thermal time parameters for germination

\begin{tabular}{lcc}
\hline Parameter & $\begin{array}{l}\text { Estimate } \pm \text { S.E. } \\
\text { for English } \\
\text { acorns }\end{array}$ & $\begin{array}{l}\text { Estimate } \pm \text { S.E. } \\
\text { for Italian } \\
\text { acorns }\end{array}$ \\
\hline $\begin{array}{l}\text { Base temperature }\left({ }^{\circ} \mathrm{C}\right) \\
\text { Thermal time for } 50 \% \text { germination } \\
\left(\theta_{50}\right) \text { (degree-weeks) }\end{array}$ & $-1.5 \pm 0.7$ & $-3.3 \pm 0.9$ \\
$\mathrm{SD}$ & $53.3 \pm 4.4$ & $61.0 \pm 5.2$ \\
$\beta_{1}$ & $35.7 \pm 3.4$ & $34.7 \pm 3.5$ \\
$\beta_{2}$ & $-2.713 \pm 0.213$ & $-3.190 \pm 0.241$ \\
\hline
\end{tabular}

(Table 3). The base temperatures for shoot emergence were positive and higher than for germination. The base temperature for shoot emergence in English acorns was about $3{ }^{\circ} \mathrm{C}$ higher than for Italian acorns (Table 4). The thermal time required for $50 \%$ emergence was about 27 weeks higher for Italian acorns. Consequently, Italian acorns had a higher thermal time requirement to achieve full shoot emergence (Fig. 3b).

Table 3 Accumulated analysis of deviance for shoot emergence count data

\begin{tabular}{lrrlrl}
\hline Change & d.f. & deviance & $\begin{array}{l}\text { mean } \\
\text { deviance }\end{array}$ & \multicolumn{1}{l}{$\begin{array}{l}\text { deviance } \\
\text { ratio }\end{array}$} & $\begin{array}{l}\text { Approx. } \\
\text { F. pr. }\end{array}$ \\
\hline + Thermal time $(\theta)$ & 1 & $14,192.026$ & $14,192.026$ & 1438.92 & $<0.001$ \\
+Time & 1 & 741.402 & 741.402 & 75.17 & $<0.001$ \\
+Provenance & 1 & 14.164 & 14.164 & 1.44 & 0.234 \\
+ Thermal time. & 1 & 127.171 & 127.171 & 12.89 & $<0.001$ \\
$\quad$ provenance & & & & & \\
+ Time. provenance & 1 & 148.297 & 148.297 & 15.04 & $<0.001$ \\
$\begin{array}{l}\text { Residual } \\
\text { Total }\end{array}$ & 89 & 877.803 & 9.863 & & \\
\hline
\end{tabular}


Table 4 Estimates of the thermal time parameters for shoot emergence

\begin{tabular}{lcc}
\hline Parameter & $\begin{array}{l}\text { Estimate } \pm \text { S.E. for } \\
\text { English acorns }\end{array}$ & $\begin{array}{c}\text { Estimate } \pm \text { S.E. } \\
\text { for Italian acorns }\end{array}$ \\
\hline $\begin{array}{l}\text { Base temperature }\left({ }^{\circ} \mathrm{C}\right) \\
\text { Thermal time for } 50 \% \text { shoot } \\
\quad \text { emergence' }\left(\theta_{50}\right)(\text { degree- }\end{array}$ & $4.9 \pm 0.3$ & $1.9 \pm 0.5$ \\
$\quad$ weeks). & & $102.2 \pm 5.5$ \\
SD & $19.72 \pm 1.63$ & $22.39 \pm 2.01$ \\
$\beta_{1}$ & $-6.900 \pm 0.527$ & $-8.278 \pm 0.632$ \\
$\beta_{2}$ & $0.09198 \pm 0.00762$ & $0.081 \pm 0.00725$ \\
\hline
\end{tabular}

3.3 Predicted germination and shoot emergence of the two provenances under reciprocal conditions

Using the thermal time parameters and climatic data, germination and shoot emergence were predicted for each provenance under reciprocal field conditions. October was used as a starting point for thermal time accumulation since acorns mature and fall during this month. Figure 4a shows the predicted germination for the two provenances under current reciprocal field conditions. For both provenances, the predicted response tracked seasons similarly in England; germination occurred rapidly in autumn, tapered off slightly during the winter and then reached maximal germination during early spring. In Italy, however, there were significant differences between the responses of the two provenances. The Italian acorns germinated rapidly in autumn, tapered off considerably during winter, but then reached maximal germination during early spring. In contrast, the English acorns began to germinate rapidly in autumn, but the rate then levelled off with little or no germination during winter and then reached maximal germination during late spring. Figure $4 \mathrm{~b}$ shows the predicted shoot emergence for the two provenances under current reciprocal field conditions. For both provenances, the predicted shoot emergence indicated a long lag until mid to late spring before the shoots emerged rapidly and reached maximum shoot emergence over summer. In addition, there were differences between the responses of provenances in each country. For Italian acorns, the predicted shoot emergence in England was about 2 weeks later than emergence in Italy. For English acorns, however, the predicted shoot emergence was about 6 or 7 weeks later in England compared to emergence in Italy.

\section{Discussion}

4.1 Temperature response curves for germination and shoot emergence

Both provenances germinated over a wide temperature range from 5 to $35^{\circ} \mathrm{C}$. At optimal temperatures $\left(15\right.$ and $\left.20^{\circ} \mathrm{C}\right)$, the shoots emerged after a short lag of 4-5 weeks, whereas at sub-
Fig. 4 Predicted germination a and shoot emergence $\mathbf{b}$ for English (squares) and Italian (circles) acorns grown under local and reciprocal conditions

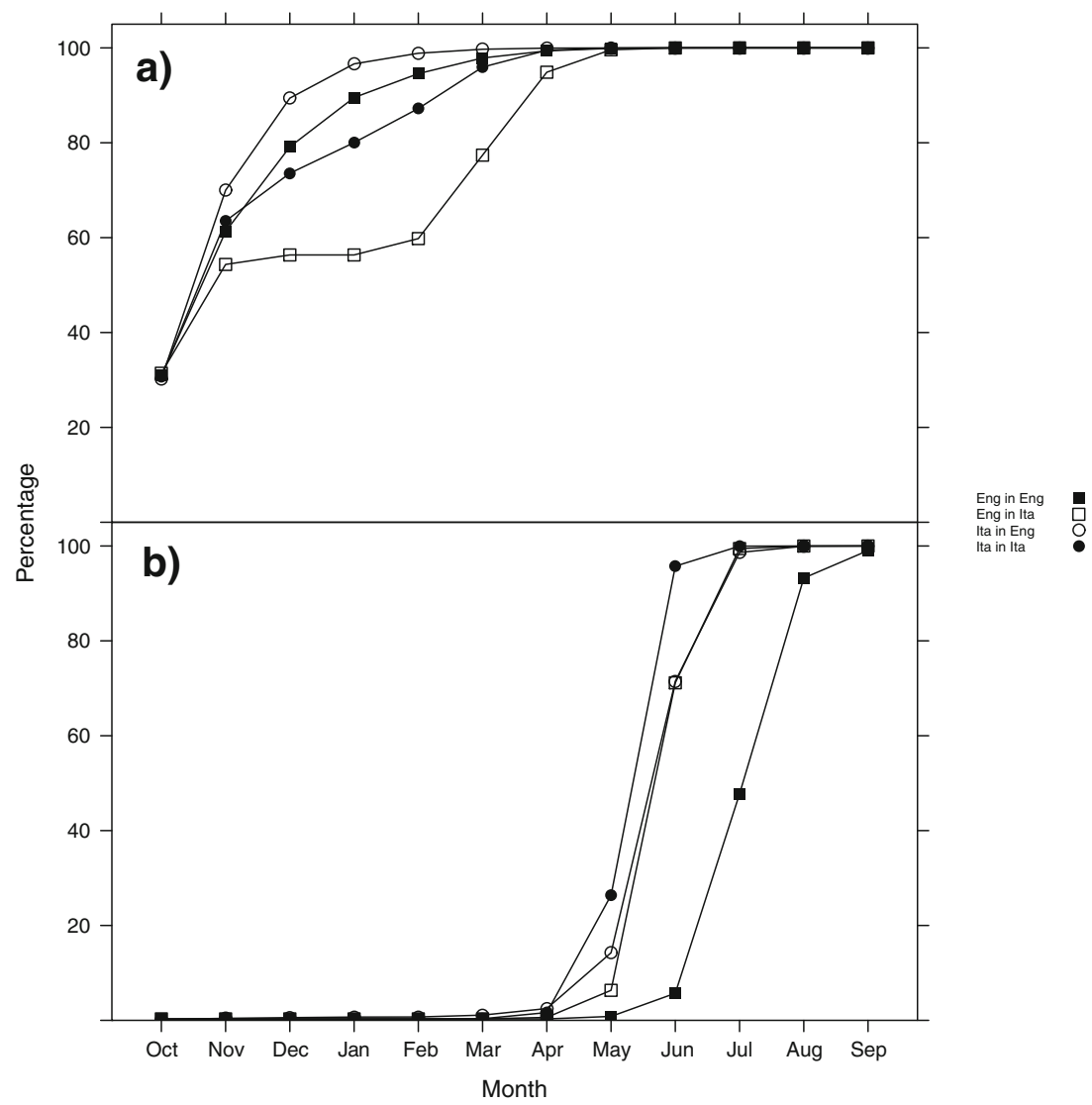


optimal temperatures $\left(10^{\circ} \mathrm{C}\right)$, the shoots emerged more slowly after a significantly longer lag (ca. 10 weeks). Similar lags between germination and shoot emergence were also reported for acorns from two Polish provenances (Suszka et al. 1996). Although no shoots emerged at $5^{\circ} \mathrm{C}$, the elongated cotyledonary petioles suggested that shoot emergence was likely given sufficient thermal time. Suszka and Tylkowski (1980) recorded some shoot emergence for pedunculate acorns incubated at $5{ }^{\circ} \mathrm{C}$ but no shoot emergence at 1 or $3{ }^{\circ} \mathrm{C}$. At supra-optimal temperatures $\left(\geq 25^{\circ} \mathrm{C}\right)$, the acorns were often unable to sustain normal growth, which resulted in stunted or deformed roots, elongated cotyledonary petioles or multi-stemmed shoots. Guibert and Le Pichon (2001) reported that a constant $20^{\circ} \mathrm{C}$ was optimal for germination and shoot emergence in sessile oak ( $Q$. petraea), but it sometimes induced the simultaneous development of various organs, resulting in artificially high numbers of multi-stemmed shoots. However, when acorns were subjected to a gradual increase in temperature $(13,16$ and $20^{\circ} \mathrm{C}$ ), there were significantly fewer seedling abnormalities. Similarly, Corbineau et al. (2001) reported multistemmed shoots in sessile oak (Q. petraea) when acorns were incubated at constant $20^{\circ} \mathrm{C}$ or higher.

\subsection{Thermal time models for germination and shoot emergence}

The thermal time models show that the thermal time parameters (base temperature and thermal time) for germination were lower than those for shoot emergence, and so the acorns accumulated thermal time more quickly for germination than for shoot emergence. Therefore, the differences between these thermal time parameters result in the temporal separation of germination and shoot emergence. So the lag between germination and shoot emergence is temperature-dependent, that is, shorter at optimal temperatures and longer at sub-optimal temperatures. At supra-optimal temperatures, this lag becomes insignificant. Consequently, the various organs often develop simultaneously, resulting in multi-stemmed shoots and other seedling abnormalities. Under natural conditions, the ambient temperatures during autumn and winter are higher than the base temperatures for germination but generally lower than those for shoot emergence. As a result, the acorns usually germinate in autumn and produce shoots several months later in spring. This phenomenon, which is considered epicotyl dormancy, has resulted in the widespread belief that a winter chill is required for shoot emergence (Wareing 1969). However, the thermal time models suggest that 'epicotyl dormancy' in $Q$. robur is simply due to the differential accumulation of thermal time above a threshold base temperature. In fact, Farmer (1977) and Wigston (1987) noted that chilling was not a requirement for shoot emergence in oaks under greenhouse conditions. The thermal time models also showed that there were significant differences between the two provenances. For both germination and shoot emergence, the base temperatures were lower for Italian acorns than English ones. Therefore, under identical conditions, the Italian acorns accumulated thermal time more rapidly than the English ones. However, the Italian acorns also required more thermal time than the English acorns for both germination and shoot emergence. This suggests that the provenances are adapted to local climatic conditions; these being colder, shorter winters in northern Italy where the spring is also warmer, shorter and arrives more rapidly compared with southern England. Pritchard and Manger (1990) also noted differences between the thermal time parameters of two provenances of pedunculate oak from England and the Netherlands. They estimated the base temperatures for germination as 0.8 and $2.4^{\circ} \mathrm{C}$ for the Dutch and English acorns respectively; these base temperatures were higher than those reported here possibly due to maternal, genotype or environmental effects (Donohue 2009; Dürr et al. 2015; Galloway 2005). Due to the lower base temperature, the Dutch acorns accumulated thermal time more quickly for germination than the English acorns. Similarly, there was a negative correlation between base temperature and thermal time; this slope reflects the selection pressure produced by the environment and human actions (Dürr et al. 2015). The log-normal distribution of thermal times within the English population also indicated that 'late germinators' required significantly longer time (about $400^{\circ} \mathrm{Cd}$ $\left[T_{b}=2.4{ }^{\circ} \mathrm{C}\right]$ ) to reach $80 \%$ germination (Pritchard and Manger 1990). Pritchard and Manger (1990) did not report information about shoot emergence.

\subsection{Predicted germination and shoot emergence of the two} provenances under reciprocal conditions

The thermal time models suggest that provenances are welladapted to local climatic conditions. The two thermal time parameters (base temperature and thermal time) provide numerous permutations for tracking climatic conditions, thus ensuring the best chance for successful germination, shoot emergence and, ultimately, seedling establishment. It is also clear from the climatic data that the two provenances face different challenges in their respective regions. With regard to temperature, there are three main differences between the two climates viz. the intensity of winter (DecemberFebruary), the onset and intensity of spring (March-May), and the intensity and duration of summer (June-August). Thus, in north-eastern Italy, winters are colder whilst summers are hotter and longer than the corresponding seasons in southern England. In addition, spring starts sooner and temperatures rise more quickly in Italy. Using our thermal time models and the climatic data, the predictions suggest that about $60 \%$ of English acorns would germinate rapidly during autumn, a further $30 \%$ more slowly over winter and the remainder in spring in England. In Italy, however, the predicted germination for 
English acorns levelled off during winter with little or no germination occurring during sub-zero ambient temperatures. In contrast, the Italian acorns are predicted to germinate in a similar pattern in both England and Italy. Pritchard and Manger (1990) also predicted that more than $50 \%$ of $Q$. robur acorns would germinate before winter and the remainder after winter once the acorns had accumulated sufficient thermal time. The amount of thermal time required though differed between provenances possibly due to genotype effects. Thus, germination of acorns is spread over several months, and therefore, ungerminated acorns are exposed to a high risk of desiccation, disease and predation. More critical though is shoot emergence; too early in England and the shoots are possibly susceptible to spring frosts, but too late in Italy and the young shoots are likely to be scorched by early summer heat. Under present climatic conditions in England, the thermal time models suggest that Italian acorns would produce shoots about 5 or 6 weeks earlier than English acorns and therefore may be susceptible to late spring frosts. This is largely due to the higher number of frost days during this period in England compared with Italy (data not shown). But under future climatic conditions (2080) projected for southern England, which approximate to present climatic conditions in northern and central regions of Italy, our model predicts little difference in the timing of shoot emergence for either English or Italian acorns; both provenances produce shoots during mid to late spring. Furthermore, the number of frost days is also likely to decrease substantially during the 2080 s (Broadmeadow and Ray 2005). Therefore, there should be less risk of frost damage for both provenances. In Q. robur, it appears that the two thermal time parameters compensate for each other so that germination and shoot emergence are constrained to 'phenological windows', which ensure synchronization with the seasons. A recent literature review showed that thermal time is negatively correlated with base temperature; species with low base temperatures required more thermal time to reach $50 \%$ germination and vice versa (Dürr et al. 2015). Therefore, germination and shoot emergence are highly plastic, adaptive responses that enable $Q$. robur to regenerate successfully in vastly different climatic conditions. Perhaps this is not surprising given that Q. robur is a flexible pioneer species with a large natural range (Hubert 2005). It is also important to note that the high carbon emissions scenario was used for predictions in the 2080s. At present, the greenhouse gas emissions are tracking this scenario and are unlikely to decrease to the low emissions scenario for the $2020 \mathrm{~s}$ and 2050s (IPCC 2007; Ray et al. 2010). In Britain, the mean annual temperature is predicted to rise by $3-6{ }^{\circ} \mathrm{C}$ with larger increases in winter than summer, particularly in southeast England (Broadmeadow and Ray 2005). In addition, rainfall is projected to increase in winter but decrease in summer, resulting in more winter floods and summer droughts respectively. Critically, the intensity and timing of rainfall affect soil water content, resulting in seasonal variations. Floods are not likely to be a particular problem for $Q$. robur, which occurs naturally in hardwood forests along floodplains. Q. robur acorns can survive soil water logging for up to 12 weeks although subsequent germination is delayed (Kühne and Bartsch 2007). As a result, the window between winter floods and summer droughts may be too narrow for seedlings to develop root systems that can tolerate the seasonal soil water deficits (Urbieta et al. 2008). This interaction between temperature and rainfall is likely to play a key role in the successful regeneration and establishment of $Q$. robur in the future.

\section{Conclusions}

Using thermal time models, the predictions suggest that Q. robur has a robust regeneration mechanism, which is well-adapted to cope with temperature shifts in a changing climate. In England, therefore, the projected temperature rises are unlikely to have an adverse effect on germination or shoot emergence of English acorns. In fact, English acorns may benefit slightly from a longer growing season if winter temperatures exceed the base temperature for shoot emergence, which is highly probable in the future climate of southeast England. In contrast, the Italian acorns are particularly susceptible to late spring frosts in the present climate in England although this risk of frost damage is reduced in the future climate. Trees are long-lived species, and therefore, this study highlights the importance of selecting seed sources that are well-adapted to both the present and future climates particularly where assisted migration forms part of a climate change adaptation strategy.

Acknowledgments The authors acknowledge Andy Peace for help with statistical analysis, Dr. Joan Cottrell for constructive criticism of the manuscript, Dr. Peter Gosling for initial discussions, Matt Parratt for technical assistance, Edward Eaton for extracting the climatic data and Michael Petr for climate-match modelling using ESC. Seed lots were purchased from Forest Enterprise (England) and Ministero delle Politiche Agricole (Italy).

Funding This project benefitted from matched funding from the Forestry Commission and the European Union (European Regional Development Fund ERDF) within the framework of the European INTERREG IV A 2 Mers Seas Zeeën Cross-border Cooperation Programme 2007-2013 (Project 090316 016-FR MULTIFOR: Management of Multi-Functional Forests) and also funding from the National Forest Company (NFC) 


\section{References}

Aitken SN, Yeaman S, Holliday JA, Wang T, Curtis-McLane S (2008) Adaptation, migration or extirpation: climate change outcomes for tree populations. Evol Appl 1:95-111. doi:10.1111/j.1752-4571. 2007.00013.x

Bewley JD, Bradford K, Hilhorst H, Nonogaki H (2013) Seeds: physiology of development, germination and dormancy, 3rd edn. Springer, New York, p 313

Broadmeadow M, Ray D (2005) Climate change and British woodland forestry commission. Research Note, Edinburgh

Broadmeadow MSJ, Ray D, Samuel CJA (2005) Climate change and the future for broadleaved tree species in Britain. Forestry 78:145-161

Côme D, Corbineau F (2006) Germination rate. In: Black M, Bewley JD, Halmer P (eds) The Encyclopedia of seeds: science technology and uses. Cromwell Press, Trowbridge, p 273

Corbineau F, Dacher F, Côme D (2001) Influence de la durée de conservation des glands au froid et de la température de germination sur le développement des plantules de chêne sessile. Rev For Fr LIII 32 43

Donohue K (2009) Completing the cycle: maternal effects as the missing link in plant life histories. Phil Trans R Soc B 364:1059-1074. Published online Mar 12, 2009. doi: 10.1098/rstb.2008.0291

Ducousso A, Bordacs S (2004) EUFORGEN technical guidelines for genetic conservation and use for pedunculate and sessile oaks (Quercus robur and Q. Petraea). IPGR, Rome, p 6

Dürr C, Dickie JB, Yang X-Y, Pritchard HW (2015) Ranges of critical temperature and water potential values for the germination of species worldwide: contribution to a seed trait database. Agric Forest Met 200:222-232. Available online at http://www.sciencedirect. com/science/article/pii/S0168192314002482\#, last accessed December 2014

Ellis RH, Covell S, Roberts EH, Summerfield RJ (1986) The influence of temperature on seed germination rate in grain legumes. II. Intraspecific variation in chickpea (Cicer arietinum L.) at constant temperatures. J Exp Bot 37:1503-1515

Farmer RE (1977) Epicotyl dormancy in white and chestnut oaks. For Sci 23:329-332

Finch-Savage W, Whalley R (2006) Germination-field emergence models. In: Black M, Bewley JD, Halmer P (eds) The encyclopedia of seeds: science technology and uses. Cromwell Press, Trowbridge, p 260

Galloway LF (2005) Maternal effects provide phenotypic adaptation to local environmental conditions. New Phyt 166:93-100. doi:10. $1111 / \mathrm{j} .1469-8137.2004 .01314$

Guibert, M., and Le Pichon, C. 2001. Influence de la température sur la germination, la levée et sur les taux de semis á tiges multiples chez le chêne sessile. Rev For Fr LIII 44-54

Harris I, Jones PD, Osborn TJ, Lister DH (2012) Updated high-resolution grids of monthly climatic observations - the CRU TS3.10 dataset. Submitted to Int J Climatol. [on-line] Available online at http://badc. nerc.ac.uk/view/badc.nerc.ac.uk_ATOM dataent_ 256223773328276, last accessed January 2013

Hewitt GM, Nichols RA (2005) Genetic and evolutionary impacts of climate change. In: Lovejoy TE, Hannah L (eds) Climate change and biodiversity. Yale Univ. Press, New Haven, pp 176-192

Hubert J (2005) Selecting the right provenance of oak for planting in Britain. FCIN077. Forestry Commission, Edinburgh. Available online at http://www.forestry.gov.uk/pdf/FCIN077.pdf/\$FILE/ FCIN077.pdf., last accessed December 2014
Hubert J, Cottrell J (2007) The role of forest genetic resources in helping British forests respond to climate change. FCIN 86. Forestry Commission, Edinburgh

Hubert J, Cottrell J (2014) Establishing and managing gene conservation units. FCPN 21. Forestry Commission, Edinburgh

Hubert J, Cundall E (2006) Choosing provenance in broadleaved trees. FCIN 82. Forestry Commission, Edinburgh

IPCC (2007) Climate change 2007- the physical science basis: contribution of working group I to the fourth assessment report of the IPCC. Cambridge University Press, Cambridge

Jinks RL, Willoughby I, Baker C (2006) Direct seeding of ash (Fraxinus excelsior L.) and sycamore (Acer pseudoplatanus L.): the effects of sowing date, pre-emergent herbicides, cultivation, and protection on seedling emergence and survival. For Ecol \& Manag 237:373-386

Jones EW (1959) Biological flora of the British Isles. Quercus L J Ecol 47:169-222

Kühne C, Bartsch N (2007) Germination of acorns and development of oak seedlings (Quercus robur L.) following flooding. J For Sci 53: 391-399

Leech SM, Lara Almuedo P, O’Neill G (2011) Assisted migration: adapting forest management to a changing climate. BC J Ecosyst \& Manag 12(3):18-34. Available online at http://jem.forrex.org/ index.php/jem/article/view/91/98, last accessed October 2014

Payne RW, Lane PW, Digby PGN, Harding SA, Leech PK, Morgan GW, Todd AD, Thompson R, Tunnicliffe Wilson G, Welham SJ, White RP (1993) Genstat 5, release 3 reference manual. Clarendon, Oxford

Pritchard HW, Manger KR (1990) Quantal response of fruit and seed germination rate in Quercus robur L. and Castanea sativa Mill. to constant temperatures and photon dose. J Exp Bot 41:1549-1557

Pritchard HW, Tompsett PB, Manger KR (1996) Development of a thermal time model for the quantification of dormancy loss in Aesculus hippocastanum seeds. Seed Sci Res 6:127-135

Pritchard HW, Steadman KJ, Nash JV, Jones C (1999) Kinetics of the high temperature germination response in Aesculus hippocastanum seeds. J Exp Bot 50:1507-1514

Pyatt DG, Ray D, Fletcher J (2001) An ecological site classification for forestry in Great Britain. Bulletin 124, Forestry Commission, Edinburgh

Ray D, Morison J, Broadmeadow M (2010) Climate change: impacts and adaptation in England's woodlands. Forestry Commission Research Note 201. Forestry Commission, Edinburgh

Ste-Marie C, Nelson EA, Dabros A, Bonneau M-E (2011) Assisted migration: introduction to a multifaceted concept. For Chron 8:724 730

Suszka B, Tylkowski T (1980) Storage of acorns of the English oak (Quercus robur L.) over 1-5 winters. Arboretum Kórnickie XXV: 199-229

Suszka B, Muller C, Bonnet-Masimbert M (1996) Seeds of forest broadleaves from harvest to sowing Translated by A.G. Gordon. INRA, France

Urbieta IR, Pérez-Ramos IM, Zavala MA, Marañón T, Kobe RK (2008) Soil water content and emergence time control seedling establishment in three co-occurring Mediterranean oak species. Can J For Res, 2008, 38(9):2382-2393, Available online at http:// www.nrcresearchpress.com/doi/abs/10.1139/X08-089, last accessed December 2014

Wareing PF (1969) Germination and dormancy. In: Morris MG (ed) Physiology of plant growth and development. McGraw Hill, New York, pp 605-644

Wigston DL (1987) Epicotyl dormancy in Quercus robur L. Q J For 81: $110-112$ 